\title{
EARLY IMPACT OF COVID-19 PANDEMIC ON ENTREPRENEURSHIP IN SLOVENIA; BASED ON GLOBAL ENTREPRENEURSHIP MONITOR DATA
}

Preliminary communication

UDK: 005.1:616.2-036.21](497.4)

JEL classification: I19, L26, 010

DOI: $10.17818 / \mathrm{DIEM} / 2022 / 1.6$

Accepted for publishing: July 8, 2021

\begin{abstract}
As the COVID-19 pandemic spreads around the globe, entrepreneurs, their ventures and societies face unprecedented challenges. Entrepreneurship fosters the innovation needed not only to take advantage of new opportunities, boost productivity and create employment, but also to address the economic shockwave triggered by the COVID-19 pandemic. Slovenia, as a small open economy, is particularly vulnerable to the effects of the pandemic. Therefore, the main objective of the paper is to analyse and compare how the entrepreneurial sector responded to the first lockdown situation in Slovenia. The data will be obtained from the Global Entrepreneurship Monitor database and the results will be compared with European countries. The question is whether the response of the entrepreneurial sector was to some extent dependent on the response of the government. The results allow a first approximation of the rapid changes that entrepreneurs have to face in order to adapt to the new scenario and prevent the deterioration of the economy or its reconstruction. Government policies need to be adapted to the economy's developmental level and depend on the type of entrepreneurship that needs to be encouraged. Policy makers need to create coherent, holistic and conducive frameworks for entrepreneurs to thrive in a post COVID -19 world. In sum, there is much potential for small businesses to contribute to the "post-covid economy", especially if they are empowered through targeted support measures.
\end{abstract}

Keywords: entrepreneurship, entrepreneurship ecosystem, government policy, COVID-19, GEM data

\section{INTRODUCTION}

The COVID-19 pandemic remains one of the most significant crises of the modern era (Alon, Farrell and $\mathrm{Li}, 2020$ ). Unlike some recent crises, Covid is a chronic health crisis that has multiple dimensions. As a global public health crisis, it has led to the closure of businesses and people staying home for months. Governments and policymakers are trying to utilize entrepreneurial thinking as a way of responding to the crisis. This policy orientation is due to the huge impact that COVID-19 has had on business and society. Encouraging entrepreneurship will be central to multiple governments around the world for the foreseeable future, especially considering the significant negative impact on economies due to the pandemic. Despite the obvious need for entrepreneurship due to COVID-19 related change, there is a lack of research that adequately explains the way entrepreneurial policy initiatives have been utilized in the crisis (Donthu and 
Gustafsson, 2020). According to Ratten (2021), entrepreneurship is essential in times of crisis as it provides a positive outlook on new conditions.

In March 2020, a coronavirus epidemic was declared in Slovenia, which was associated with enormous negative socio-economic impacts on the economic and social situation. The greatest initial negative impacts were observed in the tourism industry due to travel disruptions, domestic logistics (especially freight to and from Italy), and the gaming industry. The automotive industry was also one of the most affected sectors: a sector that was already in a downturn before the outbreak. COVID-19 contributed to its decline through supply chain disruptions and logistical breakdowns. Various studies conducted in Slovenia during the pandemic show that almost all economic entities faced serious business problems due to lower demand, social distancing measures and disrupted supply chains (Economy snapshot, GEM 2020). According to Močnık, Crnogaj, Bradač Hojnik and Crnogaj (2021), more than half of SME companies plan to accelerate their digitalization, with most of them belonging to the service sector.

Motivated by an interest in COVID-19 and entrepreneurship, this article discusses how the entrepreneurial sector responded to the first lockdown situation in Slovenia and how the national government is helping the sector. Data are drawn from the Global Entrepreneurship Monitor database and results are compared with European countries. Governments and other stakeholders will increasingly need hard, robust and credible data to make key decisions that stimulate sustainable forms of entrepreneurship and promote healthy entrepreneurial ecosystems worldwide. During its 22-year existence, Global Entrepreneurship Monitor (GEM) has repeatedly contributed to such efforts. The question of this research is whether the response of the entrepreneurial sector has been to some extent dependent on the response of the government. Policymakers around the world have grappled with the question of how to implement policies that protect the health of citizens while encouraging economic development. Such a task is not easy, as the contrasting needs of multiple stakeholders need to be considered. The results provide a first approximation of the rapid changes that entrepreneurs have to face in order to adapt to the new scenario and prevent the deterioration of the economy or its reconstruction.

\section{ENTREPRENEURSHIP ECOSYSTEM}

Exploring the entrepreneurship field requires the implementation of multiple levels of consideration that are not mutually exclusive but complement one another. The reasons for considering a multi-level analysis lies in the characteristics of the entrepreneurship phenomenon itself, which takes place and has an impact on different social levels simultaneously (Davidsson and Wiklund, 2001). Welter and Smallbone $(2011,107)$ state that the majority of entrepreneurship research focuses on the micro-level of explanation, while it is becoming increasingly clear that the entrepreneurial behavior should be considered in the context in which it occurs in the first place. The latter involves the institutional level, formed by the economic, political and cultural environment in which the entrepreneur operates (Shane, 2003). The socio-cultural and the politicoinstitutional environment influence the entrepreneurial attitudes and motives, the resources that can be mobilized as well as the constraints and opportunities in/for starting and running a business (Martinelli, 2004, in: Welter and Smallbone, 2011, 108). The external macro environment can enable and encourage the entrepreneurial activity, but it can also slow it down and influence the enterprise's competitive attitude.

Given that a positive relationship between entrepreneurship and economic growth/development has been demonstrated, improving institutional conditions for entrepreneurship is crucial to designing appropriate government policies. While formal institutions include economic and political arrangements, such as government, judicature and bureaucracy, informal ones include e.g. values, norms, taboos, customs and the social networks. Both formal and informal institutions strongly influence the incentive structure in a country and, consequently, generate economic performance (North, 1991). The soundness of institutions, the adequacy of 
infrastructure, macroeconomic stability, the soundness of the health care system and the suitability of basic education in the institutional framework can be seen as basic requirements for the development of successful entrepreneurship (Bosma et al., 2008). Therefore, the factors that contribute to greater efficiency and innovation in the economy can only be enforced in the creation of these fundamental conditions.

Fostering entrepreneurship has become a core component of economic development in cities and countries around the world. The prevailing metaphor for fostering entrepreneurship as an economic development strategy is the "entrepreneurship ecosystem." This represents a shift away from company specific interventions towards more holistic activities that focus on developing networks, aligning priorities, building new institutional capabilities and fostering synergies between different stakeholders (RodriguezPose, 2013; Warwick, 2013). The term ecosystem was originally coined by James Moore in an influential article in Harvard Business Review published in the 1990s. He claimed that businesses don't evolve in a "vacuum" and pointed to the relationally embedded nature of how firms interact with suppliers, customers and financiers (Moore, 1993). The concept of an "ecosystem" is increasingly used in management and business to describe collectives of heterogeneous, yet complementary organizations that collectively create some kind of system-level output, analogous to an "ecosystem service" delivered by natural ecosystems, and which goes beyond the outputs and activities of any individual participant of the ecosystem (Llewellyn and Autio, 2020). The environment in which entrepreneurial individuals live and work significantly influences their decision to set up a company or to expand an existing one (Isenberg, 2010, 2011; Mason and Brown, 2014; Spigel, 2017; Stam and Spigel, 2018; Stam and van de Ven, 2019). The entrepreneurship ecosystem thus represents a fundamental starting point to design and implement the public policy in cities, regions or at the level of national economy.

The entrepreneurship ecosystem consists of hundreds of specific elements. According to Mason and Brown (2014), based on a synthesis of definitions found in the literature, the definition is as follows: "a set of interconnected entrepreneurial actors (both potential and existing), entrepreneurial organisations (e.g. firms, venture capitalists, business angels, banks), institutions (universities, public sector agencies, financial bodies) and entrepreneurial processes (e.g. the business birth rate, numbers of high growth firms, levels of "blockbuster entrepreneurship", number of serial entrepreneurs, degree of sellout mentality within firms and levels of entrepreneurial ambition) which formally and informally coalesce to connect, mediate and govern the performance within the local entrepreneurial environment". In entrepreneurship ecosystems, ecosystem participants each operating in a specialized role that requires specialized expertise, yet the roles are interdependent in the sense that none of the ecosystem participants alone is able to create the ecosystem output (Llewellyn and Autio, 2020). Another significant distinction from other economic policy approaches is that the entrepreneurial ecosystem approach not only sees entrepreneurship as a result of the system, but also sees the importance of entrepreneurs as key actors (leaders) in the creation of the system and keeping it healthy (Stam, 2015; Acs et al., 2017).

As discussed, an entrepreneurship ecosystem consists of all the elements required to sustain entrepreneurship in a particular territory. Building on previous studies through the years, there are a number of models of entrepreneurial ecosystems. For example, OECD Entrepreneurship Measurement Framework, Ahmad and Hofman, 2007; Isenber's entrepreneurship ecosystem model, 2011; World Economic Forum entrepreneurship ecosystem - WEF, 2013; Entrepreneurship ecosystem model "Six + Six", Kotai and Company, 2014; Entrepreneurial Ecosystem Index, Stam, 2017; Entrepreneurial Ecosystem Quality Compisite Index - ESI, Gem Consortium, 2020, ect. For example, Stam and van de Ven (2019) propose an integrative model of entrepreneurial ecosystems consisting of ten elements and entrepreneurial outputs (Figure 1). 


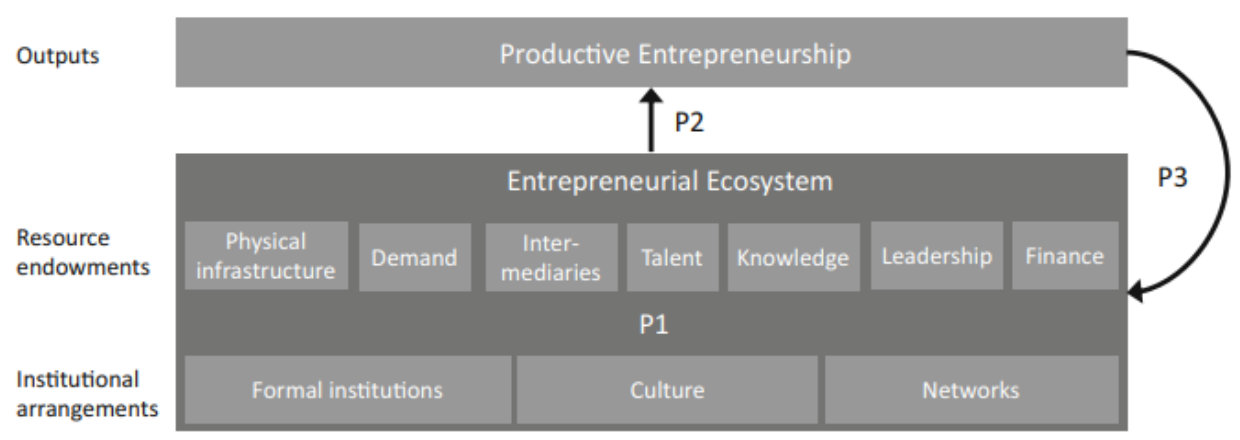

Source: Stam and van de Ven, 2019.

Figure 1 Elements and outputs of the entrepreneurial ecosystem

The ten elements are operational constructs of the broader concepts of institutions and resources of an entrepreneurial ecosystem. The proposed entrepreneurial ecosystem includes the institutional arrangements and resource endowment components of the infrastructure. The institutional arrangements component is captured by the formal institutions, culture and network elements. The resource endowment component is captured by the physical infrastructure, finance, leadership, talent, knowledge, intermediate services and demand elements. The third component of the infrastructure, proprietary functions, consists of the entrepreneurial firms commercializing innovations. This component is regarded to be the output of the entrepreneurial ecosystem, conceptualized as new value creation and captured by productive entrepreneurship (Stam and van de Ven, 2019). The presence of these elements and the interdependence between them are crucial for the success of the ecosystem.

From the definitions and proposed models of the entrepreneurship ecosystem, it is clear that entrepreneurs need to be adequately supported by various stakeholders in order to improve their performance and maintain sustainability. Mutual interaction and synergy between public and private partners contributes to setting up healthy pillars that support the development of entreprenerurial activity. A quality national business framework brings many benefits to entrepreneurs and increases their competitiveness. The recent popular literature on entrepreneurial ecosystems directly addresses the key stakeholders in the ecosystem, mainly entrepreneurial leaders and policy-makers. According to Audretsch and Link (2012), policymakers concerned with economic development have sought to identify policy "levers" with which to encourage higher levels of entrepreneurial activity resulting in economic growth and job creation.

\subsection{Government policy}

During the COVID crisis businesses need to be flexible in order to survive in the new market conditions. Governments around the world responded quickly and vigorously to the unprecedented challenges that SMEs are facing due to the COVID-19 pandemic, through a wide range of incentive and support measures. These measures focus on emergency liquidity support in various forms, but have gradually been complemented by structural support and broader recovery packages. Both central and regional and local governments joined in the policy effort (OECD, 2021). 


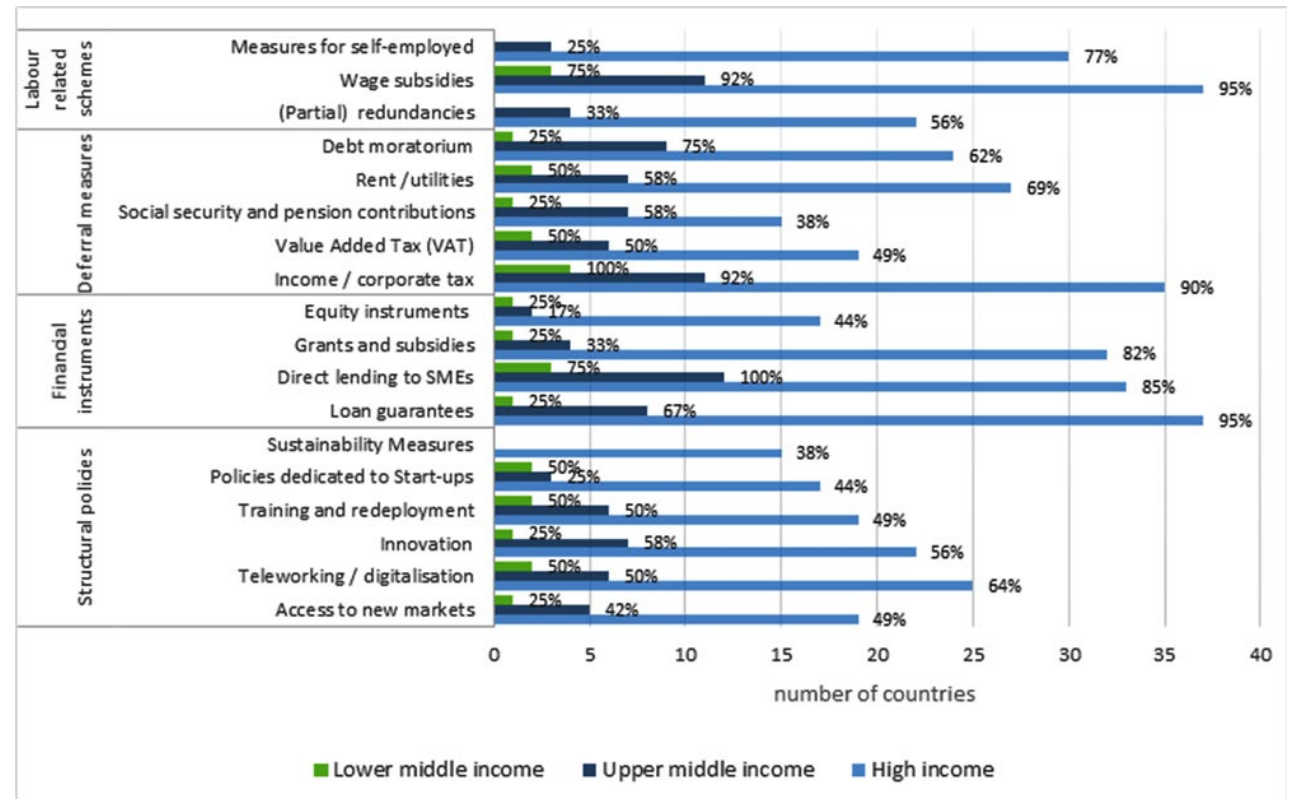

Source: OECD, 2021.

Figure 2 SME support measures introduced as a response to the COVID-19 crisis by group of countries according to their income levels (February 2020 - February 2021)

Each country and geographical area has its own features that define entrepreneurship. Understanding entrepreneurship in one's own country means comparing it with others while being aware of the fact that entrepreneurship has different impacts in terms of national economic development phases (Crnogaj et al., 2015). Such an approach makes it possible to learn each other and, in an effort to support entrepreneurship, to implement those measures that have proven to be effective in similar circumstances or developmental phases. Entrepreneurship unleashes economic development only when appropriate institutional backgrounds are in place (Baumol 1990; Boettke and Coyne 2003; Powell 2008; in Stam et al. 2011). Many government furlough schemes and other governmental mechanisms were set up to support businesses through the pandemic, particularly in Europe and the United States. While these schemes have proved essential in safeguarding jobs and businesses, they are not without their drawbacks, given that blanket schemes cannot easily distinguish between viable and unviable businesses. To a large extent, entrepreneurship in such crises is necessity-driven; however, these entrepreneurial activities may, directly or indirectly, eventually generate secure and established businesses, and productive jobs and employment for many (Bosma et. al, 2021).

Policymakers worldwide have been grappling with how to implement policies that protect the health of citizens while encouraging economic development. Such a task is not easy, as the contrasting needs of multiple stakeholders need to be considered. A glance at the economic conditions of countries that have successfully decreased the infection rates of COVID-19 reveals that their efficiency is due to the implementation of effective policies, thereby advancing a competitive advantage in the global market. Therefore, cooperation between policymakers and business entities can facilitate economic growth and stimulate new economic gains (Ratten, 2021).

\section{DATA AND METHODOLOGY}

Data from the Global Entrepreneurship Monitor (GEM) were used for this study. Since its inception in 1999, the Global Entrepreneurship Monitor is the only source of information that provides an estimate of the average state of environmental conditions for starting new businesses. The 
literature identifies the following as essential environmental conditions for entrepreneurs to develop their activities with adequate support: 1. Financing for entrepreneurs 2. Government policies (support and relevance on the one hand and taxation and regulation on the other hand) 3 . Government programmes for entrepreneurs 4. Entrepreneurship education and training (in the school stage on the one hand, and in the postschool stage on the other hand) 5 . R\&D transfer 6 . Access to and availability of business and professional infrastructure 7. Opening of the internal market (its dynamics, on the one hand, and its barriers and regulations on the other hand) 8 . Access to and availability of physical infrastructure and services 9 . Social and cultural norms.

The analysis of the environmental conditions for entrepreneurship makes it possible to identify the strengths and weaknesses of a country's context that are conductive to the interaction of economic actors and, in particular, those that can promote entrepreneurship in different areas. This tool consists of a comprehensive questionnaire administered to a sample of selected experts in these environmental conditions in each country. The expert survey methodology is widely used by various reputable sources of information (e.g. the WEF Global Competitiveness Report) and is applied in order to measure concepts for which there are no other objective sources of information. In the case of the National Expert Survey - NES, each participating country must select at least 4 experts per condition $(4 \times 9=36)$, providing a sample of at least 36 experts. $25 \%$ of the experts must be active as entrepreneurs or established businesspeople. The questionnaire is structured in blocks of items that are constructs measuring a latent concept. All variables are measured on a Likert scale of 0-10 points, whereby $0=$ completely insufficient and $10=$ completely sufficient. Applying a Principal Component Analysis (PCA) to each block of items and using the entire sample of experts from all countries provides the latent variables, which are 12 in total. As a measure of reliability and internal consistency, Cronbach's Alpha is calculated for all constructs before conducting principal component. The results are stable over 20 years, with values ranging from 0.7 to over 0.9 for all blocks, ensuring the robustness of the methodology.

For this study, we used data from the latest 2020/2021 GEM survey, which includes NES data from 45 countries (with a total of 1,821 participaring experts). The data are of great value because they reflect the state of the environment at the time of the first lockdowns and in the first months of the pandemic. Descriptive statistics and linear regression were used to interpret the results.

\section{RESEARCH RESULTS}

By surveying a large number of carefully selected national experts (entrepreneurs, managers and other individuals from the economy, politics, government administration and academia who have experience and knowledge in various fields related to entrepreneurship), we gain insight into the main conditions of the entrepreneurial context. 


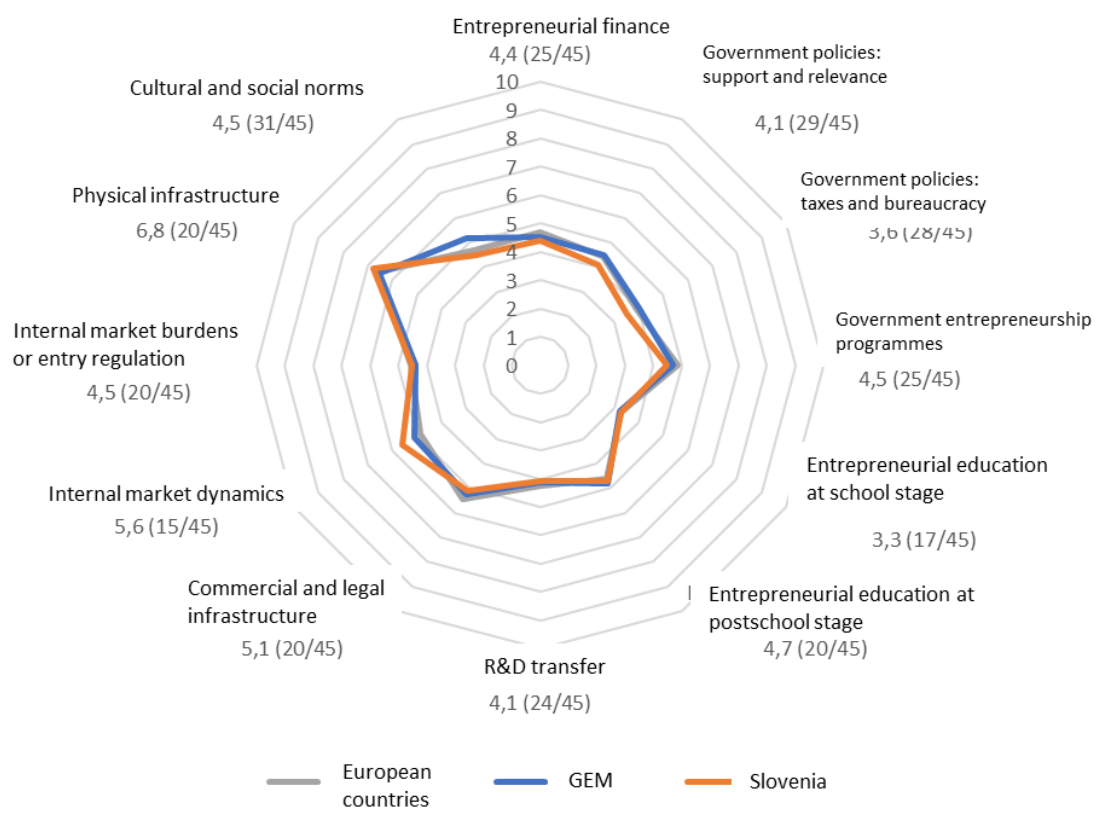

Notes: rank out of 45 recorded in brackets

Source: author's research

Figure 3 Expert ratings of the entrepreneurial framework conditions in Slovenia compared to European countries and GEM countries

In 2020, Slovenia scored higher than the European average on four framework conditions, with internal market dynamics and physical infrastructure scoring highest. These two frameworks received higher average scores than the overall GEM average. Even though commercial and professional infrastructure in Slovenia was rated positively, the comparison with European economies shows that there are still possibilities for improvement in this area. The same applies to access to entrepreneurial finance. On the other hand, it is encouraging that in 2020 the Slovenian national experts' average scores for entrepreneurship education as well as social and cultural norms either came close to or surpassed the European average.

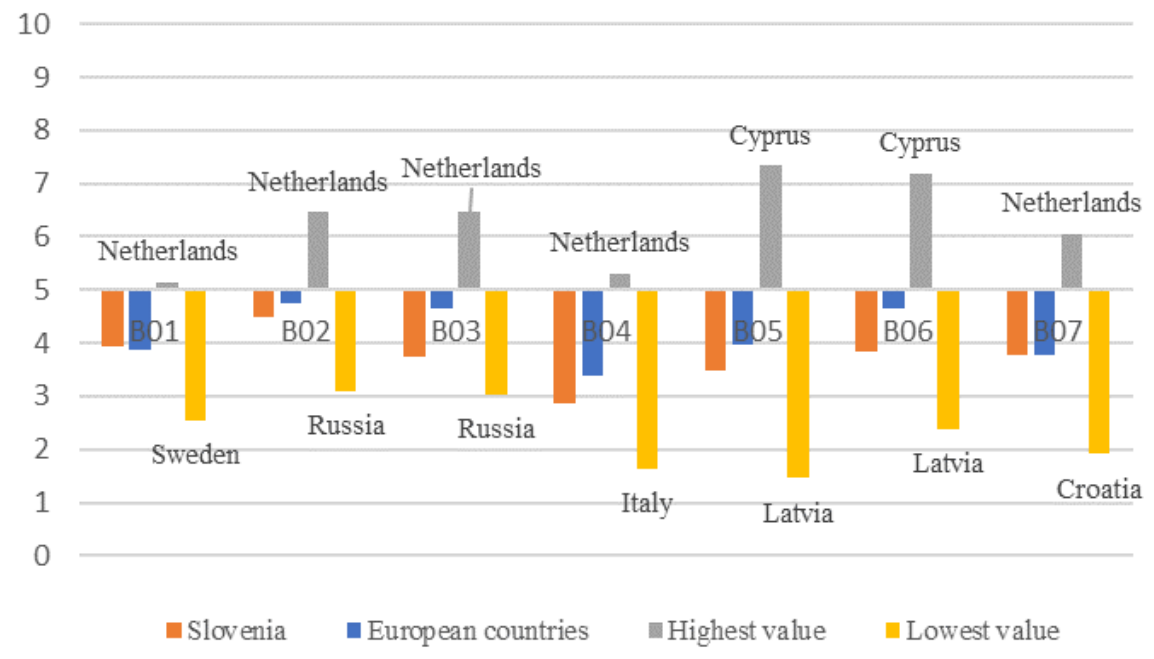


Government policy

B01 government policies (e.g., public procurement, legislation, regulation, licensing, taxation) consistently favor new firms.

B02

the support for new and growing firms is a high priority for policy at the national government level

B03 the support for new and growing firms is a high priority for policy at the local government level

B04 new firms can get most of the required permits and licenses in about a week.

B05 the amount of taxes is NOT a burden for new and growing firms.

B06 taxes and other government regulations are applied to new and growing firms in a predictable and consistent way.

B07 coping with government bureaucracy, regulations, and licensing requirements is not unduly difficult for new and growing firms.

Notes: weighted average, $0=$ completely insufficient and $10=$ completely sufficient

Source: author's research

Figure 4 Government policy rating

In 2020, Slovenian national experts were most critical towards the speed of obtaining required permits and licenses (average score of 2.88). Concerning government policy, the experts gave the highest average score (4.49) to the statement that the support for new and growing businesses is a high priority for policy at the national government level, which still ranks Slovenia below the European average. In addition, Slovenia ranked far below the European average regarding the government policy priority in terms of supporting new and growing businesses at the level of municipalities and administrative units. This is followed by the unpredictability of and the inconsistency in the application of taxes and other government regulations to new and growing businesses. Based on the national experts' scores, the Netherlands has the best practice in the European context when it comes to dealing with bureaucracy and government regulations. Moreover, this country frequently has the highest average scores when it comes to different elements of entrepreneurship-related government policy.

When it comes to entrepreneurship-related government policies, the most frequent constraining factors identified by Slovenian experts were the inconsistencies of support measures, resource scattering among different stakeholders in the supporting environment, and the lack of transparency and coordination among the stakeholders. On the other hand, they identified several fostering factors for Slovenian entrepreneurship: efficient support network at regional and local levels (i.e., Innovative Environment Network (SIO), Slovenia Business Point (SPOT) offices, the activities of the Chamber of Craft and Small Business of Slovenia and the Chamber of Commerce and Industry of Slovenia and Regional development agencies), as well as bottom-up initiatives such as Start:up Slovenia Initiative as an active coordinator and promoter of public and private stakeholders in the Slovenian start-up ecosystem.

As the pandemic coincided with the start of data collection for the GEM 2020 cycle, the GEM technical and scientific team reacted quickly, and developed batteries of questions related to the impact of the pandemic in its information tools. Specifically, in the expert survey, it inserted two blocks of questions. One to capture the opinion of the experts about the way in which the entrepreneurs' sector reacted to the lockdown situation and another to press their opinion about the measures taken by national governments to help the sector. 


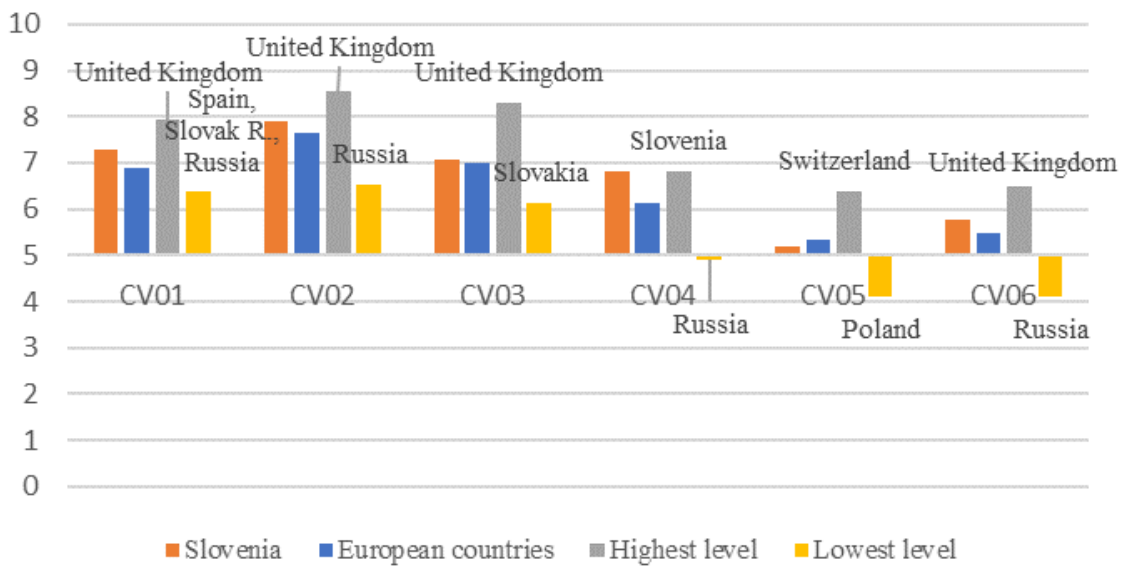

\begin{tabular}{|c|c|}
\hline CV01 & $\begin{array}{l}\text { A substantial number of new and growing firms are adopting new } \\
\text { ways of doing business as a result of the COVID } 19 \text { pandemic }\end{array}$ \\
\hline CV02 & $\begin{array}{l}\text { A substantial number of new and growing firms are promoting } \\
\text { working from home as a result of the COVID } 19 \text { pandemic }\end{array}$ \\
\hline CV03 & $\begin{array}{l}\text { A substantial number of new and growing firms are making } \\
\text { adjustments to their current products and services to adapt to the } \\
\text { COVID } 19 \text { pandemic }\end{array}$ \\
\hline CV04 & $\begin{array}{l}\text { A substantial number of new and growing firms are identifying plenty } \\
\text { of new opportunities because of the COVID } 19 \text { pandemic }\end{array}$ \\
\hline CV05 & $\begin{array}{l}\text { Cooperation between and within new and growing firms and/or } \\
\text { established firms has increased as a result of the COVID } 19 \text { pandemic }\end{array}$ \\
\hline CV06 & $\begin{array}{l}\text { A substantial number of new and growing firms are collaborating on } \\
\text { global social activities, challenges and proposals, as a result of the } \\
\text { COVID } 19 \text { pandemic }\end{array}$ \\
\hline
\end{tabular}

Notes: $0=$ nothing proactive, $10=$ fully proactive

Source: author's research

Figure 5 Entrepreneurs' response to the COVID-19 lockdown and consequences

The overall average score of the framework, which refers to the response of the business sector in Slovenia to the pandemic is 6.73. The result means that new and growing businesses in Slovenia have responded proactively to lockdown due to the COVID-19. The rating places Slovenia in the top half of all participating GEM countries and above the European average (6.46).

According to the national experts, many new and growing companies in Europe quickly adapted to the new situation resulting from the pandemic (introduced new ways of doing business, encouraged work from home, adapted their products and services, discovered new business opportunities, etc.). In Slovenia, the experts rated five of the six statements in this framework with average ratings above the European average. The statement that many new and growing businesses are discovering many new opportunities due to the COVID-19 pandemic was even given the highest average rating among all European countries. However, entrepreneurs are somewhat more reluctant to make this claim. As part of the GEM Adult Populations Survey (APS), only $32.33 \%$ of early entrepreneurs believe that the pandemic has provided new business opportunities that they intend to take advantage of in the company. This places Slovenia in line with the European average. Slightly below the average of European countries, Slovenian experts rated the statement that cooperation between new, growing and/or established companies in Slovenia has increased due to the COVID-19 pandemic. The statement is generally the lowest in Slovenia, with an average score of 5.19. During the outbreak of the pandemic in Slovenia, the 
largest decline in business was recorded in the service sector, especially tourism, as well as in the automotive industry, transport and the industrial sector, together with media and education (AmCham, Kearney, 2020). On the other hand, retail sales of personal protective equipment, household goods, and leisure industry products and services increased. Companies from these industries recorded positive sales during the coronavirus outbreak. The positive impact of the coronavirus outbreak was felt in the ICT sector, as private and public institutions introduced remote working by their employees. According to some studies, companies are planning to accelerate the digitalization of internal processes and maintain teleworking, and are planning to robotize processes; most of these companies come from the service sector. Some companies are increasing their investments in digitalization and in mergers and acquisitions, developing transformational actions to emerge as winners from the crisis. A growing number of companies, particularly in the chemical and healthcare sectors, are already developing post-crisis transformation plans. Almost $50 \%$ are preparing for both internal transformation and market opportunities, and expect the state not to set national boundaries and to work to maintain a single European market. They also expect that the planned measures will be successfully implemented at the state level.

Despite the proactive response of the business sector, early government policy response has received lower results. Thus, the improvement in the social perception of entrepreneurship in 2020 could explain why experts rated Slovenia's entrepreneurial response to the pandemic as slightly stronger than the governmental response. Slovenian experts assessed this framework with an average score of 4.92 (on a scale of 0 to 10), while the average for European countries was 5.29.

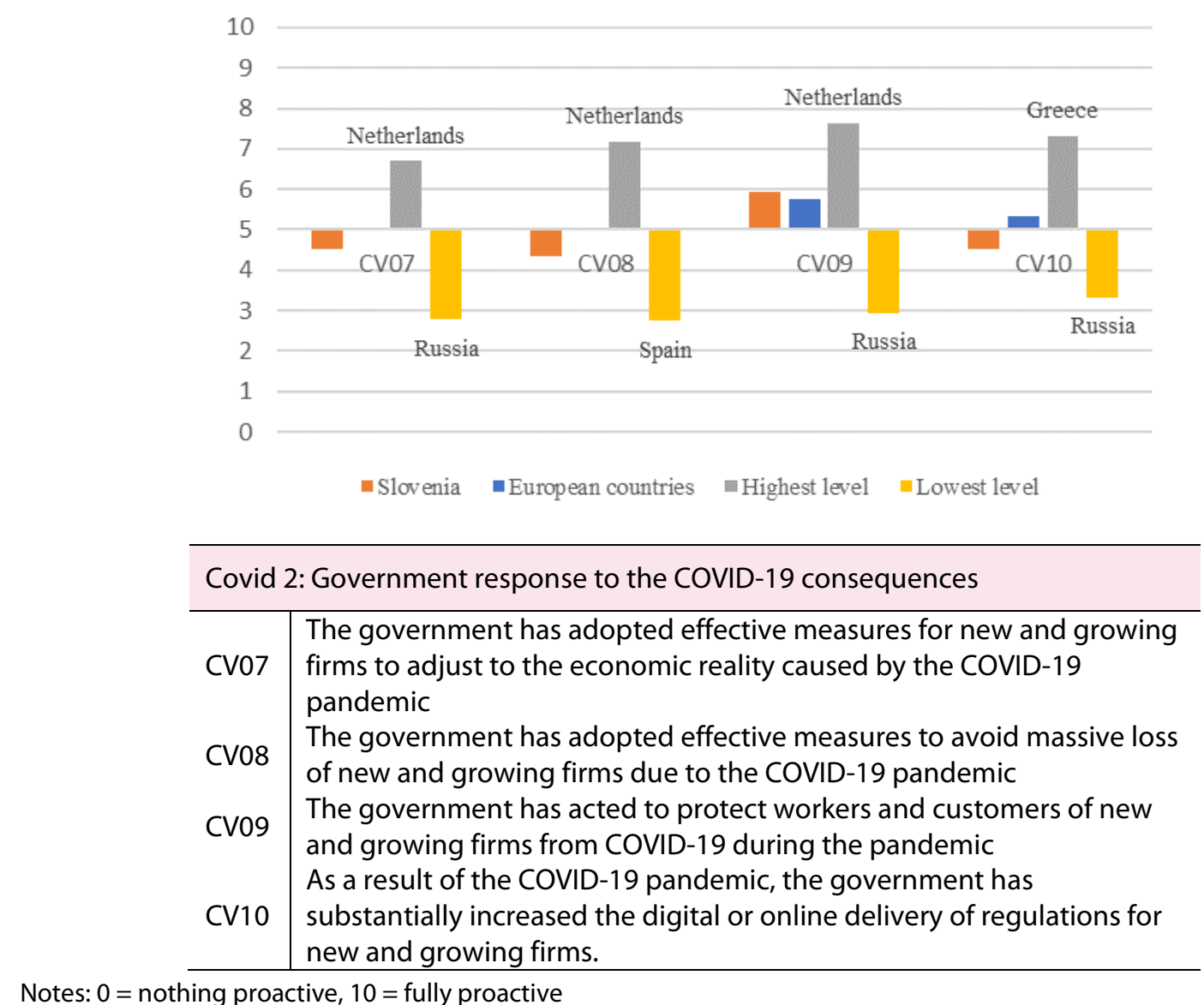

Source: author's research

Figure 6 National Governments' response to the COVID-19 lockdown and its consequences for the entrepreneurial sector 
Globally, government action is rated highest in Saudi Arabia, followed closely by the United Arab Emirates and the Netherlands. The Netherlands is a country where entrepreneurial activity has traditionally enjoyed great support.

A linear regression analysis shows that there is no significant dependence between the responses of both sectors to the lockdown when considering the whole sample of countries. Regarding this result, it must be considered that experts from half of the countries represented viewed the government's response as insufficient with some variability while half of the countries considered it sufficient or higher. Both entrepreneurs and governments reacted at the same time and with different intensities depending on the country in question. So, the result suggests that there are at least two types of behaviours or models within the general regression model:

1) A group of countries where the entrepreneurial sector reacted proactively almost independently from a governmental response perceived as insufficient.

2) A group of countries where governments and the entrepreneurial sector are perceived as reacting proactively while at the same time coordinating their efforts to some degree.

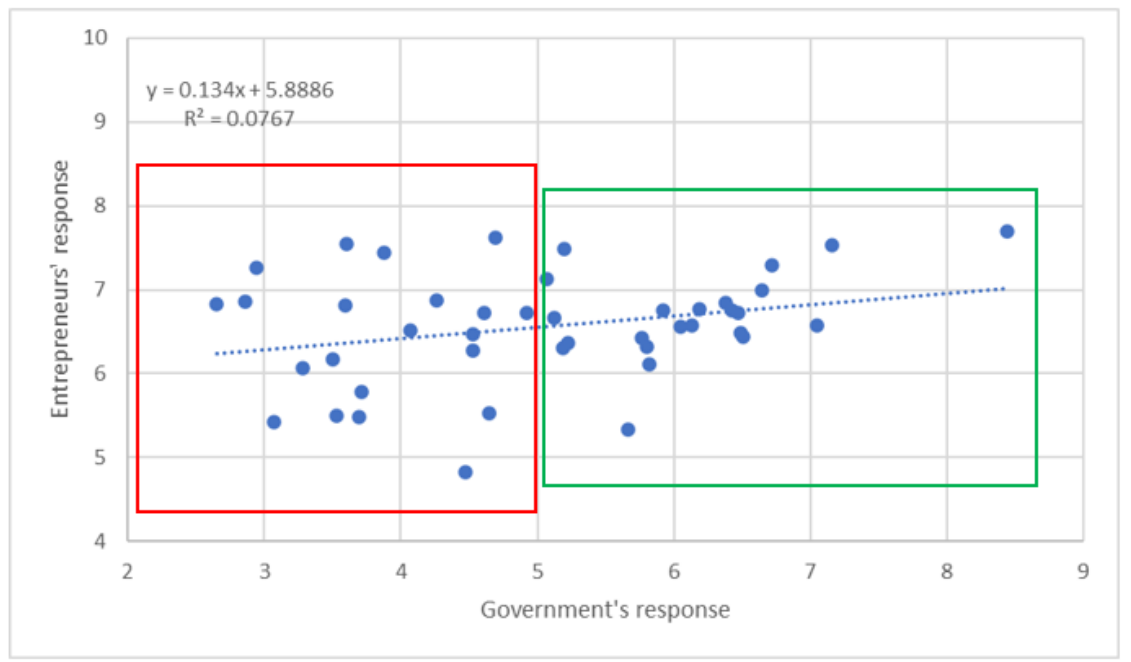

Source: GEM-NES, 2021; author's research

Figure 7: Linear regression between the entrepreneurial sector response and the government response to the first COVID-19 lockdown

Thus, if we separate countries, we obtain a regression model in which the response of both sectors is somewhat weak but still significantly and positively related. In this model, governmental response explains $32.6 \%$ of the entrepreneurs' response to the first lockdown. The estimated model indicates that, on average, when the government response increases 1 point, the response of the entrepreneurial sector increases almost 0.43 points. Therefore, it is found that a proactive reaction by governments to the economic consequences derived from the health crisis caused by the COVID-19 is very positive in terms of helping new and growing companies to survive and ultimately prosper (GEM-NES, 2021). Taking protective action that prevents closure and loss of employment - and that enables continuity in generation of wealth - both positively contributes to and complements the efforts that entrepreneurs make themselves.

The lower average assessment of the government response in the first months of the epidemic in Slovenia can be attributed to the low average assessment of government policies. A more detailed survey of a sample of all participating countries showed that there is a positive relationship between government policies and government response to the impact of the pandemic. It can be deduced that the stronger the government support for the entrepreneurial sector, the more proactive the government's response to the situation. However, in a situation like 
the current one, the lack of support measures for companies can lead to the closure of many activities in many countries and the loss of many jobs within a few months.

\section{CONCLUSIONS}

Business environment in which companies operate has a strong influence on nascent and new businesses as well as established ones. The entrepreneurship ecosystem, which encompasses many different stakeholders that have an impact on entrepreneurial activity, is an important part of this business environment. The environment influences both the emergence and development of entrepreneurship; therefore, identifying policies that lead to appropriate levels of entrepreneurial activity is a significant challenge (Bosma 2012, 35). Based on our findings, it will be critical in developing economies to stimulate growth through entrepreneurship to address the rising unemployment caused by the COVID-19 pandemic, where governments should act as "connectors, evaluators and interlocutors" to support local entrepreneurs. By partnering with entrepreneurial systems, governments can attract engaged and innovative citizens to achieve sustainable growth that creates jobs.

The changes COVID-19 has made present a variety of challenges and opportunities for entrepreneurs. These entrepreneurs, known for their skill and resourcefulness, are likely to develop new ways to address these issues, to operate and compete, to take new strategic directions, and to make innovative moves to navigate the new global competitive landscape. Although it presented a challenge for some businesses in terms of their operations, many entrepreneurs saw it as the emergence of new business opportunities. Entrepreneurship is certainly not a "one fits all" approach, but rather an inclusive and iterative process that is dependent on external enablers. In a forthcoming brave new post-COVID-19 world, businesses need to increase their adaptability by improving their flexibility, resilience and responsiveness. In principle, it is impossible to achieve business growth in a small local or national market, which is why ambitious Slovenian businesses must have a strong international orientation.

According to Weick and Sutcliffe (2011), new policy recommendations have emerged regarding innovative ways that society has learned to deal with changing work, living, and business conditions. Policy entrepreneurship and its contribution to COVID-19 processes increasingly appear high on the current governmental agendas (Ratten, 2021). As indicated, government should focus on the entrepreneurial framework conditions - creating a stable, supportive framework that is conducive to entrepreneurship, where people do not lose their entrepreneurial spirit, where their fear of failure is reduced, and where they can venture forward to establish and grow vibrant and profitable businesses. Due to the changing nature of COVID-19, it has become apparent that new strategies need to be developed by emphasizing the practicality and timeliness of policies. The increased awareness of government policy makers in Slovenia has led to greater efforts and energy being put into strengthening support for businesses in terms of various resources provision and improving the entrepreneurial framework conditions. This in turn boosts the engagement of existing entrepreneurial talent and the attraction of new one.

The impact of the economic crisis due to the COVID-19 pandemic has not yet been fully captured with the 2020 data. The 2021 evaluations and results will more clearly show the impact of the COVID-19 induced crisis on the entrepreneurial framework conditions. With the advent of COVID-19 and the new environment it has created, there is a wealth of opportunity for creative and rigorous scholarship in the field.

\section{REFERENCES}

Acs, Z. J., Stam, E., Audretsch, D. B. and O'Connor, A. (2017). The Lineages of the Entrepreneurial Ecosystem Approach. Small Business Economics, 49(1), pp. 1-10. https://doi.org/10.1007/s11187-016-9801-2; https://doi.org/10.1007/s11187-017-9864-8 
Ahmad, N. and Hoffman, A. (2007). A Framework for Addressing and Measuring Entrepreneurship. Entrepreneurship Indicators Steering Group. OECD. Available: https://www.oecd.org/sdd/businessstats/39629644.pdf

Alon, I., Farrell, M., and Li, S. (2020). Regime type and COVID-19 response. FIIB Business Review, pp. $1-9$. https://doi.org/10.1177/2319714520928884

AmCham, Karney (2020). AmCham Karney COVID-19 flash survey, may, 2020, available: https://www.amcham.si/upload/custom/Kearney\%20\%20AmCham\%20-Covid19\%20Flash\%20 Survey\%20_vS.pdf

Baumol, W.J. (1990). Entrepreneurship: Productive, Unproductive, and Destructive. Journal of Political Economy, 98 (5), pp. 893-921. https://doi.org/10.1086/261712

Boettke, P. and Coyne, C.J. (2003). Entrepreneurship and Development: Cause or Consequence?, Advances in Austrian Economics, 6, pp. 67-88. https://doi.org/10.1016/S1529-2134(03)06005-8

Bosma et al. (2021). Global Entrepreneurship Monitor 2020/2021 Global Report. Gem Consortium. Available: https://www.gemconsortium.org/reports/latest-global-report

Bosma, N., Coduras, A., Litovski, Y. and Seaman, J. (2012). GEM Manual, A Report on the Design, Data and Quality Control of the Global Entrepreneurship Monitor. GEM Working Papers.

Bosma, N., Jones, K., Autio, E. and Levie, J. (2008). Global Entrepreneurship Monitor: 2007 Executive Report. Babson College, London Business School, and GERA.

Crnogaj, K., Rebernik, M. and Bradač Hojnik, B. (2015). Supporting Economic Growth with the Innovation-oriented Entrepreneurship. Ekonomický časopis (Journal of Economics), 63 (4), pp. 395-409.

Davidsson, P. and Wiklund, J. (2001). Levels of Analysis in Entrepreneurship Research: Current Research Practice and Suggestions for the Future. Entrepreneurship Theory and Practice, 25 (4), pp. 81-100. https://doi.org/10.1177/104225870102500406

Donthu, N. and Gustafsson, A. (2020). Effects of COVID-19 on business and research. Journal of Business Research, 117, pp. 284- 289. https://doi.org/10.1016/j.jbusres.2020.06.008

Economy snapshot, GEM 2020 (2020). Policy Brief Slovenia. Available: https://www.gemconsortium. org/economy-profiles/slovenia-2/policy

Gem Consortium (2020). Presenting the GEM ESI Diagnostic Tool. GEM Consortium. Available: https://www.gemconsortium.org/news/Presenting\%20the\%20GEM\%20ESI\%20diagnostic\%20tool

GEM NES-NECI (2021). GEM NECI Explanatory Notes. Global Entrepreneurship Reasearch Association, GERA.

Isenberg, D. J. (2010). How to Start a Entrepreneurial Revolution. Harvard Busines Review, 88 (6), pp. 41-50.

Isenberg, D. J. (2011). The Entrepreneurship Ecosystem Strategy as a New Paradigm for Economy Policy: Principles for Cultivating Entrepreneurship. Babson Entrepreneurship Ecosystem Project. Babson Park, MA: Babson College.

Koltai and Company LLC (2014). International Entrepreneurship Ecosystem Development. Available: https://www.koltai.co/

Llewellyn, D. W. T. in Autio, E. (2019). Innovation Ecosystems. SSRN Electronic Journal: https://ssrn. com/abstract $=3476925$

Martinelli, A. (2004). The Context of Entrepreneurship: The ase of Ethnic Entrepreneurs. The Tocqueville Review, 25 (2), pp. 81-107. https://doi.org/10.3138/ttr.25.2.81

Mason, C. and Brown, R. (2014). Entrepreneurial Ecosystems and Growth Oriented Entrepreneurship. Background paper prepared for the workshop organised by the OECD LEED Programme and the Dutch Ministry of Economic Affairs on Entrepreneurial Ecosystems and Growth Oriented Entrepreneurship, The Hague, Netherlands.

Močnik, D., Crnogaj, K., Bradač Hojnik, B., Širec, K. (2021). Poslovno prestrukturiranje slovenskih podjetij. In: M Rebernik, K. Širec (eds.) Slovenska podjetja in značilnosti poslovnega prestrukturiranja: Slovenski podjetniški observatorij 2020. Maribor: Univerzitetna založba Univerze v Mariboru, 81-146. Available: https://press.um.si/index.php/ump/catalog/book/563. https://doi.org/10.18690/978-961-286-460-6

Moore, J. (1993) Predators and Prey: A New Ecology of Competition. Harvard Business Review. May North, D.C. (1991). Institutions. Journal of Economic Perspectives, 5 (1), pp. 97-112. https://doi.org/10.1257/jep.5.1.97 OECD (2021). One year of SME and entrepreneurship policy responses to COVID-19: Lessons learned to "build back better". Oecd Policy Responses to Coronavirus (COVID-19). OECD April 2021. Available: 
https://www.oecd.org/coronavirus/policy-responses/one-year-of-sme-and-entrepreneurship-policy-responses-tocovid-19-lessons-learned-to-build-back-better-9a230220/

Powell, B. (2008), Making Poor Nations Rich. Entrepreneurship and the Process of Economic Development. Stanford, CA, USA: Stanford University Press.

Ratten, V. (2021). COVID-19 and entrepreneurship: Future research directions. Strategic Change, Special Issue: COVID-19 and entrepreneurship, 20 (2), pp. 91-98. https://doi.org/10.1002/jsc.2392

Rodriguez-Pose, A. (2013). Do Institutions Matter for Regional Development? Regional Studies, 47, pp. 10341047. https://doi.org/10.1080/00343404.2012.748978

Shane, S. (2003). A General Theory of Entrepreneurship. The Individual-Opportunity Nexus. Cheltenham, UK; Northampton, MA, USA: Edward Elgar. https://doi.org/10.4337/9781781007990

Spigel, B. (2017). The Relational Organization of ntrepreneurial Ecosystems. Entrepreneurship Theory and Practice, 41 (1), pp. 49-72. https://doi.org/10.1111/etap.12167

Stam, E. (2015). Entrepreneurial Ecosystems and Regional Policy: A Sympathetic Critique. European Planning Studies, 23 (9), pp. 1759-1769. https://doi.org/10.1080/09654313.2015.1061484

Stam, E. (2017). Measuring Entrepreneurial Ecosystems. Utrecht University, School of Economics. Available: https://www.uu.nl/sites/default/files/rebo_use_dp_2017_1711.pdf. https://doi.org/10. 1007/978-3-319-63531-6_9

Stam, E., Hartlog, C., van Stel, A. and Thurik, R. (2011). Ambitious Entrepreneurship, High-Growth Firms, and Macroeconomic Growth. In: Minniti, M (ed.), The Dynamics of Entrepreneurship; Evidence From the Global Entrepreneurship Monitor Data, NY: Oxford University Press, 231-249. https://doi.org/10.1093/ acprof:0so/9780199580866.003.0011

Stam, E., and Spigel, B. (2018). Entrepreneurial Ecosystems. In: R. Blackburn, D. De Clercq, J. Heinonen, in Z. Wang (eds.), Sage handbook for entrepreneurship and small business. Sage Publications Ltd.

Stam, E., and van de Ven, A. (2019). Entrepreneurial cosystem Elements. Small Business Economics, https://doi.org/10.1007/s11187-019-00270-6. https://doi.org/10.1007/s11187-019-00270-6

Warwick, K. (2013). Beyond Industrial Policy: emerging issues and new trends, OECD Science, Technology and Industry Policy Papers, No 2. OECD Publishing

WEF (2013). Entrepreneurial Ecosystems Around the Globe and Company Growth Dynamics. Report Summary. WEF. Available: http://www3.weforum.org/docs/WEF_EntrepreneurialEcosystems_Report_2013.pdf

Weick, K. E. and Sutcliffe, K. M. (2011). Managing the unexpected: Resilient performance in an age of uncertainty (Vol. 8), New York: John Wiley \& Sons.

Welter, F. and Smallbone, D. (2011). Institutional Perspectives on Entrepreneurial Behavior in Challenging Environments. Journal of Small Business Management, 49 (1), pp. 107-125. https://doi.org/10.1111/j.1540627X.2010.00317.x 